\title{
Hasil Pengujian Proksimasi Dan Gas Buang Pada Briket Campuran Limbah Serutan Kayu, Sekam Padi Dan Bulu Ayam
}

\author{
Muhamad Rizky Adipratama ${ }^{1}$, Reza Setiawan ${ }^{2}$, Najmudin Fauji ${ }^{3}$ \\ ${ }^{1,2,3}$ Teknik Mesin, Universitas Singaperbangsa Karawang \\ 1rizkypratama2229@gmail.com, ${ }^{2}$ reza.setiawan@staff.unsika.ac.id, ${ }^{3}$ najmudin.fauji@staff.unsika.ac.id
}

\begin{abstract}
Biomass energy is one that can be used as an alternative energy as a substitute for fossil fuels and can also be useful for reducing environmental pollution due to increasing waste or waste. The manufacture of briquettes from chicken feather waste, wood shavings and rice husk waste aims to help deal with the problem of waste and use it as an alternative fuel. The making of briquettes is carried out by the process of drying the ingredients, charcoal, milling, sieving, kneading, printing, drying, proximate testing and measuring emissions on the briquettes. In this study, the composition of a mixture of chicken feathers $(30 \%, 40 \%, 50 \%)$, wood shavings and rice husk $(35 \%, 30 \%, 25 \%)$ was treated as well as particle sizes of 30 mesh and 60 mesh. The results of this study indicate that the lowest moisture content is in sample B2 of $4.5 \%$. The lowest levels of volatile matters were in sample A1 of $37.4 \%$. The lowest ash content was found in sample B3 at $10.8 \%$. The highest fixed carbon was found in sample A3 at 45.1\%. The highest calorific value (Gross Calorific Value) is found in the B3 sample of $5594 \mathrm{Kcal} / \mathrm{Kg}$. And it has the highest $\mathrm{CO}, \mathrm{CO}_{2}$, and $\mathrm{HC}$ emissions produced from the briquettes, namely $0.24 \%, 0.8 \%, 46$ ppm. The properties of briquettes that have met SNI standards are moisture content, calorific value (except for sample A1), and the resulting emissions. And those that have not met SNI standards are the levels of volatile matter, ash content and fixed carbon. The resulting briquette can be used because the calorific value obtained is quiet high, which is above the specified standard of $\geq 5000 \mathrm{Kcal} / \mathrm{Kg}$.
\end{abstract}

Keywords: briquettes, proximate test, heating value, emission.

\begin{abstract}
Abstrak
Energi biomassa menjadi salah satu yang dapat dimanfaatkan sebagai energi alternatif sebagai pengganti bahan bakar fosil juga dapat berguna untuk mengurangi pencemaran lingkungan akibat sampah atau limbah yang terus bertambah. Dibuatnya briket dari limbah bulu ayam, limbah serutan kayu dan sekam padi bertujuan untuk membantu menangani permasalahan limbah dan memanfaatkannya menjadi bahan bakar alternatif. Pembuatan briket dilakukan dengan proses pengeringan bahan, pengarangan, penggilingan, pengayakan, pengadonan, pencetakan, penjemuran, uji proksimat dan pengukuran emisi pada briket. Pada penelitian ini memiliki perlakuan komposisi campuran bahan bulu ayam $(30 \%, 40 \%, 50 \%)$, serutan kayu dan sekam padi $(35 \%, 30 \%$, 25\%) serta ukuran partikel 30 mesh dan 60 mesh. Hasil dari penelitian ini menunjukan Kadar air terendah terdapat pada sampel B2 sebesar 4,5\%. Kadar zat terbang terendah terdapat pada sampel A1 sebesar 37,4\%. Kadar abu terendah terdapat pada sampel B3 sebesar 10,8\%. Kadar karbon tertinggi terdapat pada sampel A3 sebesar 45,1\%. Nilai kalor (Gross Calorific Value) tertinggi terdapat pada sampel B3 sebesar $5594 \mathrm{Kcal} / \mathrm{Kg}$. Dan memiliki emisi $\mathrm{CO}_{2} \mathrm{CO}_{2}$, dan $\mathrm{HC}$ tertinggi yang dihasilkan dari briket tersebut yaitu sebesar $0,24 \%, 0,8 \%, 46 \mathrm{ppm}$. Sifat briket yang telah memenuhi standar SNI yaitu pada kadar air, nilai kalor (kecuali pada sampel A1), dan emisi yang dihasilkan. Dan yang belum memenuhi standar SNI yaitu pada kadar zat terbang, kadar abu, dan kadar karbon. Briket yang dihasilkan dapat digunakan karena nilai kalor yang didapat cukup tinggi yaitu di atas standar yang ditentukan sebesar $\geq 5000 \mathrm{Kcal} / \mathrm{Kg}$.
\end{abstract}

Kata kunci: briket, uji proksimat, nilai kalor, emisi.

\section{Pendahuluan}

Saat ini di Indonesia sebagian besar penggunaan energinya berasal dari bahan bakar fosil, yaitu gas, batu bara, dan minyak. Kerugian penggunaan bahan bakar fosil ini selain merusak lingkungan, juga tidak terbarukan (nonrenewable) dan tidak berkelanjutan (unsustainable) [1]. Karena meningkatnya penggunaan bahan bakar di Indonesia setiap tahunnya, kita juga dituntut untuk dapat meningkatkan efisiensi penggunaan energi. Sebagai langkah untuk dapat meningkatkan efisiensi penggunaan energi, kita bisa mengembangkan dan menggunakan sumber-sumber 
energi yang ada di sekitar kita untuk dijadikan sumber energi alternatif. Biomassa adalah suatu energi atau bahan bakar yang diperoleh dari mahkluk hidup dan sumber alami yang dapat diperbaharui. Biomassa merupakan bahan yang dapat diperoleh dari tanaman baik secara langsung maupun tidak langsung dan dimanfaatkan sebagai energi atau bahan dalam jumlah yang besar [2]. Biomassa merupakan berbagai jenis material organik seperti tanaman, limbah hewan, limbah pertanian, dan berbagai limbah industri yang berupa bahan organik. Prinsip kerja biomassa adalah merubah sisa-sisa bahan biologis tersebut menjadi bentuk lain yang nanti dapat dijadikan sumber energi.

Energi biomassa sangat bermanfaat karena selain kita bisa menggunakannya sebagai energi alternatif juga dapat berguna untuk mengurangi pencemaran lingkungan akibat limbah yang terus bertambah setiap tahunnya. Sampah di Karawang menjadi salah satu masalah yang hingga saat ini masih meresahkan. Beberapa jenis sampah seperti bulu ayam, serutan kayu, dan sekam padi belum dimanfaatkan dengan optimal. Menurut data dari Badan Pusat Statistik (2017), padi yang dihasilkan di Karawang mencapai 1,6 juta ton Gabah Kering Panen (GKP). Dari hasil produksi padi menghasilkan limbah sekam sebanyak (15-20)\% [3]. Menurut data dari Badan Pusat Statistik (2016), populasi unggas di Karawang mencapai 10 juta ekor. Dari hasil pengolahan ayam potong itu sendiri mengasilkan limbah bulu ayam sekitar 6\% dari bobot tiap ekornya [4]. Limbah-limbah tersebut dapat dimanfaatkan menjadi bahan bakar alternatif yang diolah menjadi arang briket karena sampah tersebut memiliki kandungan karbon yang cukup baik.

Briket arang merupakan serbuk arang yang diubah bentuk, ukuran, dan kerapatan dengan cara pengepresan serbuk arang dengan campuran perekat. Briket arang juga merupakan bahan bakar alternatif padat yang terbuat dari bahan organik yang dikeraskan, mengandung karbon, mempunyai nilai kalor yang cukup tinggi, dan dapat menyala pada waktu yang relatif lama.

Bulu ayam dapat dimanfaatkan sebagai bahan campuran untuk membuat briket karena memiliki kandungan protein yang tinggi yaitu $80-90 \%$ dari bahan kering dan dalam protein itu sendiri terdapat unsur Karbon (C), Hidrogen (H), Oksigen (O), dan sedikit Nitrogen $(\mathrm{N})$. Dan adapun unsur kimia yang terkandung dalam bulu ayam antara lain: $81 \%$ protein, $1,2 \%$ lemak, $86 \%$ bahan kering, dan $1,3 \%$ abu [5]. Unsur karbon tersebut jika diubah menjadi arang akan menghasilakn panas yang cukup baik, maka dari itu bulu ayam dapat digunakan sebagai bahan untuk pembuatan briket.
Serutan kayu ini dapat digunakan sebagai bahan campuran untuk pembuatan briket karena serutan kayu mengandung: selulosa $39-45 \%$, hemiselulosa $15-25 \%$, kadar air 5\%, lignin 18\%, dan kadar abu $1 \%$ [1]. Namun persentase kandungan yang terdapat pada serutan kayu berbeda-beda setiap jenis kayunya, seperti kayu jenis mahoni yang memiliki kandungan selulosa $35-50 \%$, hemiselulosa 20-30\%, dan lignin 25-30\%. Limbah serutan sangat cocok untuk dijadikan bahan briket karena mudah didapat dan murah.

Sekam padi adalah kulit terluar yang membungkus butiran beras, dimana kulit padi akan terpisah dan menjadi limbah. Sekam padi juga cocok digunakan sebagai campuran untuk dijadikan bahan briket kerena sekam padi mengandung kadar air 32,40 41,35\%, Serat 31,37-49,92\%, Abu 13,16-29,04\%, Pentosa 16,94-21,95\%, Selulosa 34,34-43,80\% dan Liguin 21,40-46,97\% [6]. Sekam padi juga baik digunakan sebagai bahan campuran karena mengandung 41\% karbon, Dimana unsur karbon bagus untuk pembakaran briket.

Pada penelitian ini, pemilihan bahan seperti bulu ayam, serutan kayu dan sekam padi untuk dijadikan briket arang karena di Karawang banyak sekali ditemukan dan belum dimanfaatkan dengan optimal. Penelitian ini bertujuan untuk mengetahui karakteristik pada briket campuran bulu ayam, serutan kayu dan sekam padi maka dilakukannya analisa proksimat, nilai kalor dan emisi yang dihasilkan.

\section{Metode Penelitian}

Dalam penelitian ini metode yang digunakan adalah eksperimen, yaitu penelitian yang dilakukan dengan pembuatan sampel berupa briket untuk di uji di balai pengujian. Penelitian lapangan yaitu dengan pengamatan secara langsung terhadap objek yang diteliti. Dalam penelitian ini pula, penulis melakukan pengumpulan data-data dari beberapa referensi seperti buku, tesis, dan karya ilmiah lainnya. Dalam bagian ini meliputi mencari, membaca dan menelaah beberapa sumber-sumber yang memuat hal-hal yang berkaitan dengan pembuatan briket yang akan penulis buat dalam penelitian ini. Kajian pustaka atau studi literatur sangat diperlukan untuk mendukung penyelesaian permasalahan yang diungkapkan dalam usulan penelitian.

\subsection{Proses Pembuatan Perekat}

Timbang takaran tepung tapioka sesuai dengan yang dibutuhkan. Lalu tepung tapioka dilarutkan dengan air dengan perbandingan 1:20. Panaskan larutan hingga mendidih sampai berubah menjadi kental atau seperti lem. 


\subsection{Proses Pembuatan Briket}

Bersihkan bahan briket yang akan digunakan seperti bulu ayam, serutan kayu, dan sekam padi agar terhindar dari kotoran dan unsur lain yang menempel. Keringkan bahan-bahan tersebut dengan cara dijemur di bawah sinar matahari sampai bahan benar-benar kering. Setelah bahan sudah benarbenar kering, lakukan pengarangan pada bahanbahan tersebut secara terpisah dengan melakukan proses karbonisasi. Setelah itu dinginkan arang bulu ayam, serutan kayu, dan sekam padi tersebut. Lakukan penghalusan terhadap arang tersebut dengan cara ditumbuk atau digerus lalu diayak dengan ayakan ukuran 30 mesh dan 60 mesh. Setelah itu arang hasil ayakan ditimbang sesuai rasio sampel penelitan yang dapat dilihat pada Tabel 1.

Tabel 1. Variasi komposisi sampel

\begin{tabular}{|c|c|c|c|}
\hline Bahan & Komposisi (\%) & $\begin{array}{c}\text { Kode } \\
\text { Sampel }\end{array}$ & $\begin{array}{l}\text { Ukuran } \\
\text { Partikel }\end{array}$ \\
\hline \multirow{6}{*}{ BA:SK:SP } & $30 \%: 35 \%: 35 \%$ & A1 & \multirow{3}{*}{30 Mesh } \\
\hline & $40 \%: 30 \%: 30 \%$ & $\mathrm{~A} 2$ & \\
\hline & $50 \%: 25 \%: 25 \%$ & A3 & \\
\hline & $30 \%: 35 \%: 35 \%$ & B1 & \multirow{3}{*}{$60 \mathrm{Mesh}$} \\
\hline & $40 \%: 30 \%: 30 \%$ & B2 & \\
\hline & $50 \%: 25 \%: 25 \%$ & B3 & \\
\hline
\end{tabular}

Keterangan:

BA : Bulu Ayam

SK : Serutan Kayu

SP : Sekam Padi

Campurkan hasil ayakan arang tersebut dengan perekat, diaduk hingga merata dan dicetak menggunakan cetakan. Hasil cetakan tersebut dikeringkan di bawah sinar matahari selama 3 hari agar kadar air yang terkandung dalam briket dapat berkurang. Dilakukan analisa proksimat, uji nilai kalor dan uji emisi gas pada setiap sampel briket.

\section{Hasil dan Pembahasan}

\subsection{Hasil Pengujian Proksimat}

Pada pengujian proksimat ini terdapat beberapa paramater seperti kadar air (moisture content), kadar zat terbang (volatile matter), kadar abu (ash content), kadar karbon (fixed carbon). Maka diperoleh hasil uji proksimat dari masing-masing sempel briket.

\subsubsection{Kadar Air (moisture content)}

Hasil kadar air pada tiap sampel briket dapat dilihat pada Tabel 2 dan Gambar 1.

Tabel 2. Kadar Air Setiap Sampel

\begin{tabular}{|c|c|c|}
\hline KODE & KADAR AIR (\%) & METODE \\
SAMPEL & KAne & \multirow{2}{*}{ ASTM D 3320-17 } \\
\hline A1 & 4.8 & \\
\hline A2 & 4.9 & \\
\hline A3 & &
\end{tabular}

\begin{tabular}{|l|l|}
$\mathrm{B} 1$ & 4.6 \\
\hline $\mathrm{B} 2$ & 4.5 \\
\hline $\mathrm{B} 3$ & 4.9 \\
\hline
\end{tabular}

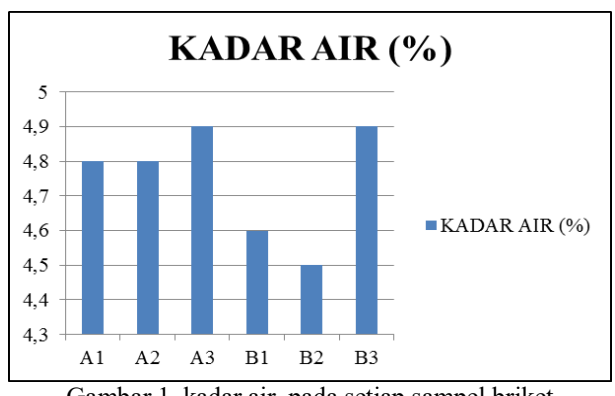

Gambar 1. kadar air pada setiap sampel briket

Berdasarkan Tabel 2 dan Gambar 1, dari segi bahan baku dan penambahan komposisi bulu ayam pada briket tidak memberikan pengaruh yang signifikan bagi kadar air yang dihasilkan karena bahan baku telah melewati proses penjemuran dan pengarangan, jadi kadar air yang terkandung pada bahan pun berkurang. Pada tabel dan grafik diatas menunjukan bahwa kadar air yang terkandung pada sampel briket B1-B3 dengan ukuran partikel 60 mesh cenderung lebih rendah yaitu dengan jumlah rata-rata 4,8\% dibandingkan dengan sampel briket A1-A3 dengan ukuran partikel 30 mesh yaitu dengan jumlah rata $4,6 \%$.

Hal ini disebabkan karena ukuran partikel serbuk arang yang berpengaruh terhadap kerapatan briket, dan kerapatan pada briket akan berpengaruh terhadap jumlah pori-pori pada briket. Semakin kecil partikel serbuk arang akan mengasilkan kerapatan yang cukup baik. Kadar air yang cukup tinggi pada briket disebabkan oleh banyaknya jumlah pori-pori yang mampu menyerap air [7]. Besarnya kadar air pada suatu briket juga dapat dipengaruhi oleh beberapa faktor seperti suhu karbonisasi, besar tekanan pada briket saat proses pencetakan, dan proses pengeringan briket untuk mengurangi kadar air pada briket akibat pencampuran dengan perekat. Kadar air terendah yang dimiliki dari setiap sampel di atas terdapat pada sampel B2 yaitu sebesar 4,5\% dan dapat memenuhi SNI briket yaitu $\leq 8 \%$.

\subsubsection{Kadar Zat Terbang (volatile matter)}

Hasil kadar zat terbang pada tiap sempel briket dapat dilihat pada Tabel 3 dan Gambar 2.

Tabel 3. Kadar Zat Terbang Setiap Sampel
\begin{tabular}{|c|c|c|}
\hline $\begin{array}{c}\text { KODE } \\
\text { SAMPEL }\end{array}$ & $\begin{array}{c}\text { KADAR ZAT } \\
\text { TERBANG }(\%)\end{array}$ & METODE \\
\hline A1 & 37.4 & \multirow{2}{*}{ ISO 562 - 2010 } \\
\hline A2 & 38.5 & \\
\hline A3 & 39.8 & \\
\hline B1 & 46.4 & \\
\hline
\end{tabular}




\begin{tabular}{|l|l|} 
B2 & 47.9 \\
\hline B3 & 48.8 \\
\hline
\end{tabular}

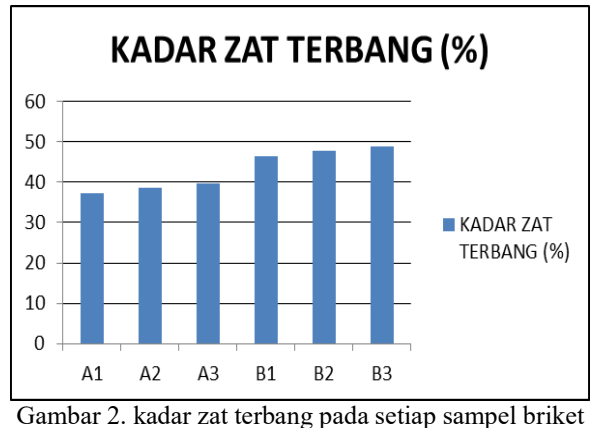

Berdasarkan Tabel 3 dan Gambar 2 penambahan komposisi pada bulu ayam dapat meningkatkan kadar zat terbang pada briket.

Kadar zat terbang pada sampel B1-B3 yang memiliki ukuran partikel 60 mesh cenderung lebih besar dibandingkan dengan sampel A1-A3 yang memiliki ukuran partikel 30 mesh. nilai kadar zat terbang tertinggi pada briket campuran tersebut dengan ukuran partikel 30 mesh dan 60 mesh terdapat pada briket dengan perbandingan komposisi $50 \%$ bulu ayam : $25 \%$ serutan kayu : $25 \%$ sekam padi yaitu pada A3 dan B3 sebesar $39,8 \%$ dan $48,8 \%$. Sedangkan nilai kadar zat terbang terendah pada briket campuran tersebut dengan ukuran partikel 30 mesh dan 60 mesh terdapat pada briket dengan perbandingan komposisi $30 \%$ bulu ayam: 35\% serutan kayu : $35 \%$ sekam padi yaitu pada A1 dan B1 sebesar $37,4 \%$ dan $46,4 \%$.

Ini menunjukan bahwa ukuran partikel pada suatu briket dapat berpengaruh pada besarnya kadar zat terbang yang dimiliki pada suatu briket. Hal ini dapat juga dipengaruhi oleh kadar abu yang terkandung pada suatu briket. semakin tinggi kadar abu yang terkandung dalam suatu briket, maka unsur-unsur lain yang mudah menguap pada bahan tersebut akan semakin sedikit dan menghasilkan kadar zat terbang yang sedikit pula [8].

Kadar zat terbang pun berpengaruh pada nilai kadar karbon, kadar zat terbang yang tinggi dapat mengurangi nilai kadar karbon tetapi tingginya kadar zat terbang juga dapat mempermudah dalam proses pembakaran pada briket karena sebagian zat terbang terdapat dalam bentuk gas yang mudah terbakar. Dari setiap sampel briket di atas kadar zat terbang terendah pada sampel A1 yaitu sebesar $37,4 \%$ ini masih sangat tinggi jika dibandingkan dengan SNI yang ditetapkan yaitu sebesar $\leq 15 \%$.

\subsubsection{Kadar Abu (ash content)}

Hasil kadar abu pada tiap sempel briket dapat dilihat pada Tabel 4 dan Gambar 3.

Tabel 4. Kadar Abu Setiap Sampel

\begin{tabular}{|c|c|c|}
\hline $\begin{array}{c}\text { KODE } \\
\text { SAMPEL }\end{array}$ & KADAR ABU (\%) & METODE \\
\hline A1 & 15.9 & \multirow{2}{*}{ ASTM D 3174-12 } \\
\hline A2 & 14.8 & \\
\hline A3 & 13.5 & \\
\hline B1 & 12.4 & \\
\hline B2 & 11.5 & \\
\hline B3 & 10.8 & \\
\hline
\end{tabular}

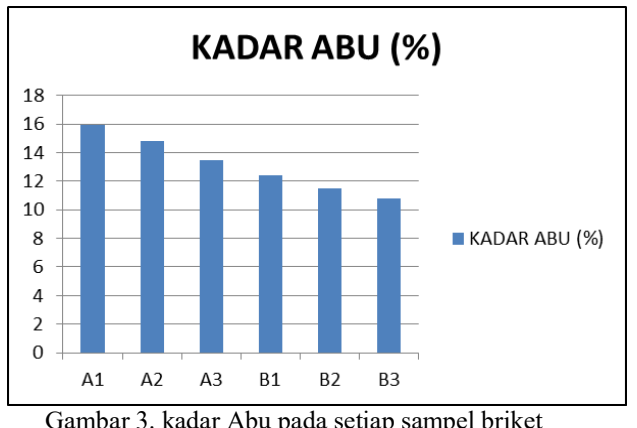

Berdasarkan Tabel 4 dan Gambar 3 terlihat bahwa kadar abu menurun seiring dengan penambahan variasi bahan bulu ayam dan pengurangan bahan serutan kayu dan sekam padi. Karena dari ketiga jenis bahan tersebut, sekam padi yang memiliki kadar abu yang cukup tinggi.

Pada perbedaan variasi partikelnya yaitu ukuran 30 mesh dan 60 mesh pun dapat mempengaruhi kadar abu yang dihasilkan. Hal ini sesuai dengan penelitian sebelumnya oleh Annisa, ukuran partikel serbuk pada briket yang lebih kecil akan menghasilkan kadar abu yang rendah [8]. Kadar abu tertinggi pada briket campuran tersebut dengan ukuran partikel 30 mesh dan 60 mesh terdapat pada briket dengan perbandingan komposisi 30\% bulu ayam : 35\% serutan kayu : 35\% sekam padi yaitu pada A1 dan B1 sebesar $15,9 \%$ dan $12,4 \%$. Sedangkan nilai kadar abu terendah pada briket campuran tersebut dengan ukuran partikel 30 mesh dan 60 mesh terdapat pada briket dengan perbandingan komposisi $50 \%$ bulu ayam : $25 \%$ serutan kayu : 25\% sekam padi yaitu pada A3 dan B3 sebesar 13,5\% dan 10,8\%.

Hal lain yang dapat mempengaruhi kadar abu pada briket yaitu pada proses karbonisasi. Kadar abu terbentuk akibat sisa pembakaran yang bersifat tidak mudah terbakar, maka kadar abu berpengaruh pada kualitas briket dimana kadar abu dapat 
menurunkan nilai kalor yang dihasilkan [9]. Maka kadar abu terendah dari sampel di atas yaitu pada sampel B3 sebesar 10,8\% masih belum dapat memenuhi SNI briket yaitu sebesar $\leq 8 \%$.

\subsubsection{Kadar Karbon (fixed carbon)}

Hasil kadar karbon pada tiap sempel briket dapat dilihat pada Tabel 5 dan Gambar 4.

Tabel 5. Kadar Karbon Setiap Sampel

\begin{tabular}{|c|c|c|}
\hline KODE & KADAR KARBON (\%) & METODE \\
\hline SAMPEL & 40.1 & \multirow{2}{*}{ ASTM D 3172 - } \\
\hline A2 & 44.2 & \\
\hline A3 & 45.1 & \\
\hline B1 & 36.6 & \\
\hline B2 & 37.4 & \\
\hline B3 & 38.2 \\
\hline
\end{tabular}

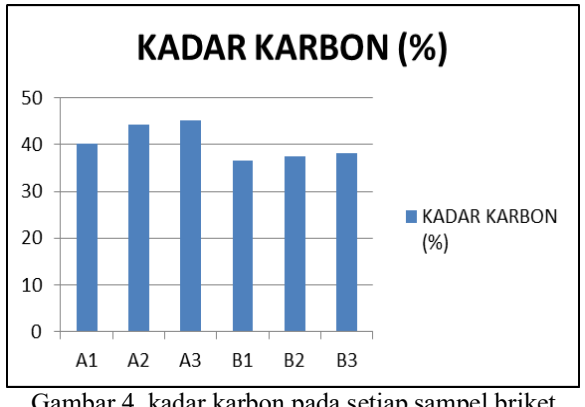

Berdasarkan Tabel 5 dan Gambar 4 Pada grafik terlihat bahwa dari A1 sampai A3 dan B1 sampai B3 kadar karbon meningkat seiring penambahan variasi komposisi bulu ayam pada briket walau tidak terlalu signifikan. Hal ini menunjukan bahwa penambahan bulu ayam pada briket dapat meningkatkan kadar karbonnya karena pada bulu ayam mengandung protein yang cukup tinggi dimana pada kandungan protein terdapat unsur karbon.

Kadar karbon tertinggi pada briket campuran tersebut dengan ukuran partikel 30 mesh dan 60 mesh terdapat pada briket dengan perbandingan komposisi $50 \%$ bulu ayam : $25 \%$ serutan kayu : $25 \%$ sekam padi yaitu pada A3 dan B3 sebesar $45,1 \%$ dan $38,2 \%$. Sedangkan nilai kadar karbon terendah pada briket campuran tersebut dengan ukuran partikel 30 mesh dan 60 mesh terdapat pada briket dengan perbandingan komposisi 30\% bulu ayam : $35 \%$ serutan kayu : $35 \%$ sekam padi yaitu pada A1 dan B1 sebesar 40,1\% dan 36,6\%.

Ada beberapa hal yang dapat memaksimalkan kandungan karbon pada sampel briket ini yaitu dengan mengeringkan bahan bulu ayam dengan maksimal misal dengan menggunakan alat pengering atau sebagainya sebelum proses pengarangan, proses pengarangan bulu ayam harus diperhatikan betul agar bulu ayam dapat menjadi arang dengan sempurna, dan proses pengarangan bahan yang lain seperti sekam padi dan serutan kayu pun harus diperhatikan agar tidak menghasilkan kadar abu yang tinggi. Kadar abu berpengaruh terhadap besarnya nilai kadar karbon [10]. kadar karbon terendah terdapat pada sampel B1 yaitu sebesar 36,6\% dan kadar karbon tertinggi terdapat pada sampel A3 yaitu sebesar 45,1\%, dimana kadar karbon tertinggi dari sampel briket ini yaitu pada sampel A3 sebesar 45,1\% masih terbilang jauh dari SNI yaitu sebesar $\geq 77 \%$.

\subsection{Hasil Pengujian Nilai Kalor (Gross Calorific Value)}

Berikut adalah nilai kalor pada briket dari masingmasing sampel dapat dilihat pada Tabel 6 dan Gambar 5.

Tabel 6. Nilai Gross Calorific Value Setiap Sampel

\begin{tabular}{|c|c|c|}
\hline $\begin{array}{c}\text { KODE } \\
\text { SAMPEL }\end{array}$ & $\begin{array}{c}\text { NILAI KALOR } \\
\text { (Kcal/Kg) }\end{array}$ & \multirow{2}{*}{ METODE } \\
\hline A1 & 4979 & \multirow{3}{*}{ ASTM D 5865-13 } \\
\hline A2 & 5340 & \\
\hline A3 & 5404 & \\
\hline B1 & 5189 & \\
\hline B2 & 5358 & \\
\hline B3 & 5594 & \\
& &
\end{tabular}

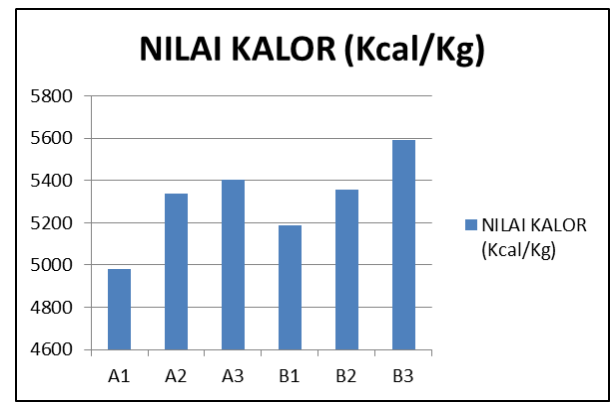

Gambar 5. Nilai Gross Calorific Value pada setiap sampel briket

Berdasarkan Tabel 6 dan Gambar 5 penambahan komposisi pada bahan bulu ayam dapat meningkatkan nilai kalor karena bulu ayam pun dapat meningkatkan kadar karbon pada briket sebab dalam nilai kalor dipengaruhi oleh kadar karbon. Hal ini menunjukan bahwa penambahan pada komposisi bulu ayam dapat menambah nilai kalor dari briket tersebut karena bulu ayam mengandung protein yang terdiri dari unsur $\mathrm{C}, \mathrm{H}, \mathrm{O}$, dan sedikit $\mathrm{N} \%$. Unsur $\mathrm{C}$ tersebut jika diubah kedalam bentuk arang dapat menghasilkan panas yang baik.

Nilai kalor tertinggi pada briket campuran tersebut dengan ukuran partikel 30 mesh dan 60 mesh terdapat pada briket dengan perbandingan komposisi 50\% bulu ayam : 25\% serutan kayu : $25 \%$ sekam padi yaitu pada A3 dan B3 sebesar 
$5404 \mathrm{Kcal} / \mathrm{Kg}$ dan $5594 \mathrm{Kcal} / \mathrm{Kg}$. Sedangkan nilai kalor terendah pada briket campuran tersebut dengan ukuran partikel 30 mesh dan 60 mesh terdapat pada briket dengan perbandingan komposisi $30 \%$ bulu ayam : 35\% serutan kayu : $35 \%$ sekam padi yaitu pada A1 dan B1 sebesar $4979 \mathrm{Kcal} / \mathrm{Kg}$ dan $5189 \mathrm{Kcal} / \mathrm{Kg}$. Dan jika dilihat dari variasi ukuran partikelnya, briket yang memiliki ukuran partikel terkecil maka dapat meningkatkan nilai kalornya. Hal ini sejalan dengan penelitian yang pernah dilakukan sebelumnya oleh Annisa (2018) yang menyatakan bahwa semakin halus partikel pada briket maka akan menghasilkan nilai kalor yang semakin tinggi [8].

Selain itu juga nilai kalor dipengaruhi oleh kadar air, kadar abu dan kadar zat terbang. Pada proses karbonisasi pun sangat berpengaruh terhadap besarnya nilai kalor. Jadi bahan baku, ukuran partikel dan proses karbonisasi sangat berpengaruh terhadap besarnya nilai kalor. Pada penelitian ini, nilai kalor yang sudah memenuhi SNI $\geq 5000$ $\mathrm{Kcal} / \mathrm{Kg}$ yaitu pada sampel A2 sebesar 5340 $\mathrm{Kcal} / \mathrm{Kg}$, A3 sebesar $5404 \mathrm{Kcal} / \mathrm{Kg}$, B1 sebesar $5189 \mathrm{Kcal} / \mathrm{Kg}$, B2 sebesar $5358 \mathrm{Kcal} / \mathrm{Kg}$, B3 sebesar $5594 \mathrm{Kcal} / \mathrm{Kg}$ dan nilai kalor yang belum memenuhi $\mathrm{SNI} \geq 5000 \mathrm{Kcal} / \mathrm{Kg}$ yaitu pada sampel A1 sebesar $4979 \mathrm{Kcal} / \mathrm{Kg}$.

\subsection{Hasil Uji Emisi}

Berikut adalah hasil pengukuran uji emisi yang dihasilkan oleh briket. Pengujian emisi ini dilakukan dengan berat masing-masing sampel yang digunakan sebesar 26 gr dengan jarak pengukuran $20 \mathrm{~cm}$ dengan menggunakan alat automotive emission analyzer. Dan masing-masing sampel diukur kadar $\mathrm{CO}, \mathrm{CO}_{2}$, dan $\mathrm{HC}$ dapat dilihat pada Tabel 7.

Tabel 7. Emisi $\left(\mathrm{CO}, \mathrm{CO}_{2}, \mathrm{HC}\right)$ Pada Setiap Sampel
\begin{tabular}{|c|c|c|c|}
\hline \multirow{2}{*}{ Kode Sampel } & $\mathrm{CO}(\%)$ & $\mathrm{CO}_{2}(\%)$ & $\mathrm{HC}(\mathrm{ppm})$ \\
\hline A1 & 0,14 & 0,4 & 31 \\
\hline A2 & 0,03 & 0,2 & 28 \\
\hline A3 & 0,01 & 0,1 & 19 \\
\hline B1 & 0,24 & 0,8 & 28 \\
\hline B2 & 0,13 & 0,6 & 35 \\
\hline B3 & 0,09 & 0,4 & 46 \\
\hline
\end{tabular}

Dari kadar CO yang di dapat pada Tabel 7 dan jika ditinjau dari konsentrasi campurannya, kadar CO terendah pada briket dengan ukuran partikel 30 mesh dan 60 mesh terdapat pada briket dengan perbandingan komposisi $50 \%$ bulu ayam : $25 \%$ serutan kayu : $25 \%$ sekam padi yaitu pada A3 sebesar 0,01\% dan B3 sebesar 0,09\%. Sedangkan kadar CO tertinggi pada briket dengan ukuran partikel 30 mesh dan 60 mesh terdapat pada briket dengan perbandingan komposisi $30 \%$ bulu ayam :
$35 \%$ serutan kayu : 35\% sekam padi yaitu pada A1 sebesar 0,14\% dan B1 sebesar 0,24\%. Hal ini menandakan semakin sedikit konsentrasi campuran sekam padi dan serutan kayu maka emisi CO yang dihasilkan pun semakin rendah. Karena pada ketiga bahan tersebut, bahan sekam padi memiliki kadar abu paling tinggi. Dimana kadar abu yang tinggi dapat menghambat pembakaran sempurna. Jika ditinjau berdasarkan ukuran partikel briket pada tabel di atas menunjukan bahwa kadar $\mathrm{CO}$ yang di hasilkan oleh briket yang memiliki ukuran partikel 60 mesh lebih besar dibandingkan briket yang memiliki ukuran partikel 30 mesh. Hal ini menunjukan bahwa partikel yang semakin kecil pada briket dapat berpengaruh dengan kadar karbon monoksida yang dihasilkan semakin besar [8].

Dari kadar $\mathrm{CO}_{2}$ yang di dapat pada Tabel 7, kadar $\mathrm{CO}_{2}$ tertinggi pada briket dengan ukuran partikel 30 mesh dan 60 mesh terdapat pada briket dengan perbandingan komposisi 30\% bulu ayam : 35\% serutan kayu : 35\% sekam padi yaitu pada A1 dan B1 sebesar $0,4 \%$ dan $0,8 \%$. Sedangkan kadar $\mathrm{CO}_{2}$ terendah pada briket campuran tersebut dengan ukuran partikel 30 mesh dan 60 mesh terdapat pada briket dengan perbandingan komposisi $50 \%$ bulu ayam : 25\% serutan kayu : 25\% sekam padi yaitu pada A3 dan B3 sebesar $0,1 \%$ dan $0,4 \%$. Maka dapat diketahui bahwa variasi pada komposisi bulu ayam, serutan kayu dan sekam padi cenderung dapat mempengaruhi kadar $\mathrm{CO}_{2}$ yang dihasilkan oleh briket tersebut. Dan ukuran prtikel yang semakin kecil pada briket cenderung meningkatkan kadar $\mathrm{CO}_{2}$ yang dihasilkan.

Pada kadar HC yang dihasilkan dari setiap sampel briket, sampel B3 yang memiliki kadar HC tertinggi yaitu sebesar $46 \mathrm{ppm}$ dan sampel A3 memiliki kadar HC yang paling rendah yaitu sebesar 19 ppm. Jika dilihat dari variasi ukuran partikel briket, sampel briket yang memiliki ukuran partikel 30 mesh memiliki kadar HC rata-rata sebesar 26 ppm sedangkan sampel briket yang memiliki ukuran partikel 60 mesh memiliki kadar HC rata-rata sebesar 36,3 ppm. Karena hidrokarbon terbentuk akibat bahan bakar yang belum terbakar tetapi ikut terbuang bersama gas buang akibat penguapan bahan bakar karena pembakaran kurang sempurna. Dalam hal ini dapat diketahui bahwa ukuran partikel pada briket dapat mempengaruhi kadar emisi HC yang di hasilkan oleh briket tersebut. Dan kadar hidrokarbon pun dipengaruhi oleh kadar air yang terkandung pada briket tersebut. Dari hasil gas buang yang dihasilkan, telah memenuhi standar dalam Peraturan menteri negara lingkungan hidup nomor 05 tahun 2006 tentang ambang batas emisi gas buang kendaraan bermotor lama yaitu kadar CO berikisar 4,5\% dan kadar HC berkisar 2000 ppm. 


\section{Kesimpulan}

Hasil penelitian dari briket campuran serutan kayu, sekam padi dan bulu ayam yang didapat melalui pengujian proksimat, pengujian nilai kalor dan pengujian emisi, maka dapat ditarik kesimpulan sebagai berikut:

1. Briket dari campuran limbah bulu ayam, limbah serutan kayu dan sekam padi ini dapat digunakan karena mempunyai kadar air, nilai kalor dan emisi gas buang yang cukup baik. Tetapi pada kadar abu, kadar zat terbang dan kadar karbonnya belum memenuhi standar SNI.

2. Kadar air terendah terdapat pada sampel B2 yaitu sebesar $4,5 \%$ dan memenuhi $\mathrm{SNI} \leq 8 \%$. Kadar zat terbang terendah terdapat pada sampel A1 yaitu sebesar $37,4 \%$ dan belum memenuhi $\mathrm{SNI} \leq 15 \%$. Kadar abu terendah terdapat pada sampel B3 yaitu sebesar 10,8\% dan belum memenuhi standar SNI $\leq 8 \%$. Kadar karbon tertinggi terdapat pada sampel A3 yaitu sebesar 45,1\% dan belum memenuhi SNI $\geq 77 \%$. Nilai kalor (Gross Calorific Value) tertinggi terdapat pada sampel B3 yaitu sebesar 5594 $\mathrm{Kcal} / \mathrm{Kg}$ dan memenuhi standar SNI $\geq 5000$ $\mathrm{Kcal} / \mathrm{Kg}$.

3. Kadar $\mathrm{CO}$ tertinggi terdapat pada sampel $\mathrm{B} 1$ yaitu sebesar $0,24 \%, \mathrm{CO}_{2}$ tertinggi terdapat pada sampel B1 yaitu sebesar 0,8\%, dan HC tertinggi terdapat pada sampel B3 yaitu sebesar 46 ppm.

\section{Daftar Rujukan}

[1] Ummi, K.., 2016. Pembuatan Briket Arang Dari Campuran Limbah Tongkol Jagung, Kulit Durian dan Serbuk Gergaji Menggunakan Perekat Tapioka. Jurnal Distilasi, 1 (1), 4250.

[2] Eddy, E., Purwo, S., dan Ahmad, S., 2014. Analisa Proksimat dan Nilai Kalor Pada Briket Bioarang Limbah Ampas Tebu dan Arang Kayu. Jurnal Aptek, 6 (1), 57-64.

[3] Badan Pusat Statistik, 2017. Luas Panen, Produktivitas, dan Produksi Padi Sawah (GKG) di Kabupaten Karawang. [Online] (Update 4 Jan 2017) Tersedia di: https://karawangkab.bps.go.id [Accessed 23 Mar 2020]

[4] Badan Pusat Statistik, 2016. Populasi Unggas Menurut Kecamatan dan Jenis Unggas di Kabupaten Karawang. [Online] (Update 3 Nov 2016) Tersedia di: https://karawangkab.bps.go.id [Accessed 25 Mar 2020]

[5] Dini, S.M., Risna, T.Y., Heri, M., dan Cahyono, P., 2016. Pemanfaatan Limbah Bulu Ayam Menjadi Bahan Pakan Ikan dengan Fermentasi Bacillus Subtilis. Jurnal Manusia Dan Lingkungan, 23 (1), 49-57.

[6] Alexius, L.O., 2014. Pengaruh Abu Sekam Padi Sebagai Bahan Pengisi Untuk Pembuatan Tungku Rumah Tangga. Jurnal Penelitian Teknologi Industri, 6 (1), 19-30.

[7] Anto, S., dan Tri, Y., 2013. Pembuatan Briket Bioarang Dari Cangkang dan Tandan Kosong Kelapa Sawit. Jurnal Teknologi Hasil Pertanian, 6 (2), 68-81.

[8] Annisa, N.S., Otong, N., dan Sri, S., 2018. Pengaruh Konsentrasi Briket Campuran Sekam Padi dan Serutan Kayu Albasia Terhadap Emisi Karbon Monoksida dan Laju Pembakaran. Jurnal Material dan Energi Indonesia, 8 (2), 25-32.

[9] Laily, N.H., dan Ardhana, R., 2017. Optimasi Kualitas Briket Biomassa Padi dan Tongkol Jagung dengan Variasi Campuran Sebagai Bahan Bakar Alternatif. Journal of Research and Technology, 3 (2), 70-79.
[10]Renny, E.P., dan Andasuryani, 2017. Studi Mutu Briket Arang dengan Bahan Baku Limbah Biomassa. Jurnal Teknologi Pertanian Andalas, 21 (2), 143-151. 